\title{
A HERPETOLOGICAL INVENTORY OF NAVAL AIR STATION FALLON, CHURCHILL COUNTY, NEVADA
}

\author{
Jonathan P. Rose ${ }^{1,4}$, Oliver J. Miano ${ }^{1}$, Gary R. Cottle ${ }^{2}$, Robert E. Lovich ${ }^{3}$, \\ Robert L. Palmer ${ }^{3}$, and Brian D. Todd ${ }^{1}$
}

\begin{abstract}
Aвstract.-Much of the western United States is managed by state and federal agencies for multiple uses, including recreation, grazing, extraction, and defense. Biological inventories are integral to proper management and conservation of biodiversity on these lands. We surveyed for amphibians and reptiles occurring on Naval Air Station Fallon (NAS Fallon), Nevada, USA, using a variety of methods. We documented the presence of a majority of the amphibian and reptile species native to this region of the Great Basin. We found 5 species on NAS Fallon that are listed as Species of Conservation Priority by the Nevada Department of Wildlife: the Great Basin Spadefoot (Spea intermontana), Western Toad (Anaxyrus boreas boreas), Northern Desert Horned Lizard (Phrynosoma platyrhinos platyrhinos), Long-nosed Leopard Lizard (Gambelia wizlizenii), and Great Basin Collared Lizard (Crotaphytus bicinctores). However, we found no evidence of any narrowly distributed species of conservation concern, such as the Northern Leopard Frog (Lithobates pipiens) or Northern Rubber Boa (Charina bottae), that could have occurred on installation lands based on historical or recent observations in nearby areas. Our results indicate that this property, while primarily used for military training, can support a diverse, representative herpetofaunal community. Therefore, NAS Fallon should be considered a valuable part of the network of state and federally managed lands necessary for regional conservation planning in the face of future change. Our study also provides a baseline against which future inventories of this federally managed land can be compared.
\end{abstract}

Resumen.-Gran parte del oeste de los Estados Unidos es administrado por las agencias estatales y federales para múltiples usos, incluyendo la recreación, el pastoreo, la extracción, y la defensa. Los inventarios biológicos son parte integral de la adecuada gestión y conservación de la biodiversidad en estas tierras. Realizamos un inventario de los anfibios y reptiles que ocurren en la Estación Aérea de la Naval en Fallon (EAN Fallon), Nevada, EE.UU., usando una variedad de métodos. Se documentó la presencia de la mayoría de las especies de anfibios y reptiles nativos a esta región de la Gran Cuenca. Encontramos cinco especies en EAN Fallon que se indican como "Especies de Conservación Prioritaria” por el Departamento de Fauna de Nevada: Sapo de espuelas de la Gran Cuenca (Spea intermontana), Sapo Occidental (Anaxyrus boreas boreas), Lagarto Cornudo del Desierto Norte (Phrynosoma platyrhinos platyrhinos), Lagartija Leopardo Narigona (Gambelia wizlizenii), y Lagarto de Collar de la Gran Cuenca (Crotaphytus bicinctores). Sin embargo, no encontramos evidencia de la presencia de especies de distribución restringida de interés para la conservación, como la Rana Leopardo (Lithobates pipiens) o la Boa de Goma (Charina bottae), que potencialmente podrían haber ocurrido en los terrenos de las instalaciones, basado en observaciones históricas o recientes en las zonas cercanas. Nuestros resultados indican que esta propiedad, aunque utilizada primordialmente para el entrenamiento militar, puede sustentar una diversa y representativa comunidad de herpetofauna. Por lo tanto, EAN Fallon se debe considerar una parte valiosa de la red de tierras administradas federalmente y por el estado necesarias para la planificación de la conservación regional ante los cambios futuros. Nuestro estudio también provee una referencia sobre la cual se pueden comparar futuros inventarios en los terrenos administrados por el gobierno federal.

Amphibians and reptiles are declining worldwide due to a combination of factors including habitat loss, disease, and overexploitation (Stuart et al. 2004, Wake and Vredenburg 2008, Todd et al. 2010). To document changes in abundance and occupancy of native fauna, it is important to have accurate baseline data on species occurrence, including species that are currently widespread and may not be immediately threatened with extinction. Indeed, monitoring occurrence and abundance of species is a vital part of adaptive management programs for biodiversity conservation (Nichols and Williams 2006). Further, a recent review of monitoring programs identified the ability to detect change as essential in monitoring efforts to avoid extinction (Lindenmayer et al. 2013). Accurate occurrence data can help alleviate the problem of "shifting baselines," where the current, degraded state of a community is

\footnotetext{
${ }^{1}$ University of California, Davis, Department of Wildlife, Fish and Conservation Biology, One Shields Ave., Davis, CA 95616.

${ }^{2}$ Naval Air Station Fallon, Environmental Division, 4755 Pasture Road Bldg. 307, Fallon, NV 89496.

${ }^{3}$ Naval Facilities Engineering Command Southwest, Desert Integrated Product Team, 1220 Pacific Highway, San Diego, CA 92132

4E-mail: jprose@ucdavis.edu
} 
accepted as natural and used as a reference point for comparing future change (Pauly 1995). Occurrence data is also necessary to develop species distribution models (SDMs), which are increasingly used for conservation decisions in the face of rapid environmental change (Guisan et al. 2013). The ability of land managers to implement appropriate management and conservation efforts for amphibians and reptiles depends on knowledge of species' presence and distribution on the landscape.

Although many species are sensitive to development and habitat alteration, the conservation of amphibians and reptiles may be compatible with some human land uses. For example, large areas in the western United States owned by the U.S. Department of Defense (DoD) and used for military testing and training purposes can support diverse assemblages of reptiles and amphibians (Adams et al. 1998, Bogosian et al. 2012). While DoD lands are subject to disturbance associated with training and testing, they often also represent large land areas exempt from many of the development pressures found elsewhere. As a result, many legally protected species occur on DoD lands though they may be extirpated elsewhere. The density of endangered species and their habitats listed under the United States Endangered Species Act (ESA) is greater on DoD lands than those controlled by any other federal agency (Stein et al. 2008). This pattern is also reflected in endangered herpetofauna, with 28 of 50 ESAlisted amphibians and reptiles in the United States occurring on military lands (Lovich et al. 2014). In fact, DoD lands are often managed with ESA-listed herpetofauna in mind, such as the federally threatened Mohave Desert Tortoise, Gopherus agassizii, at Fort Irwin, California (Esque et al. 2005), and the endangered Reticulated Flatwoods Salamander, Ambystoma bishopi, on Eglin Air Force Base, Florida (Eglin Air Force Base 2010).

Large portions of many DoD installations provide relatively undisturbed habitat for amphibian and reptile species that are currently common. In recent years, the DoD has begun developing a strategic plan for managing DoD lands for both common and threatened amphibians and reptiles (Lovich et al. 2014). Thus, along with areas explicitly established to conserve scenic landscapes and natural habitats (e.g., National Parks, National Wildlife Refuges), DoD lands provide an important component to the network of protected areas useful in conserving biodiversity in the face of anthropogenic change.

Herein, we report the results of a study conducted to inventory the reptiles and amphibians of Naval Air Station Fallon (NAS Fallon) in Churchill County, Nevada, USA. These DoD lands are potentially important for the management of both common species and Nevada Species of Conservation Priority (SOCP), such as the Northern Leopard Frog (Lithobates pipiens) and Columbia Spotted Frog (Rana luteiventris) (Wildlife Action Plan Team 2012), given their limited distributions in Nevada, known occurrences near NAS Fallon, and recent petitions for their listing under the ESA. We document the occurrence of amphibians and reptiles that inhabit NAS Fallon. Our results can aid land administrators in managing habitats for native amphibians and reptiles and provide a baseline for future herpetological surveys and monitoring aimed at detecting change in occupancy and distribution of these species.

NAS Fallon covers approximately $975 \mathrm{~km}^{2}$ near the city of Fallon in Churchill County, Nevada, USA. NAS Fallon contains military training areas and 4 active bombing ranges closed to the public, along with areas open to the public for uses such as camping and hunting. We surveyed 8 widely dispersed parcels of NAS Fallon: Main Station, Dixie Valley Meadows, Dixie Valley Settlement Area, Dixie Valley Training Area, Horse Creek, and 3 bombing ranges (B-16, B-17, B-19) (Fig. 1). NAS Fallon lies within the Great Basin Desert Ecoregion at elevations ranging from 1190 to $2440 \mathrm{~m}$ above sea level. Habitats in NAS Fallon include desert scrub dominated by Bailey's greasewood (Sarcobatus baileyi) and sagebrush (Artemisia spp.), grasslands, rocky canyons, riparian willow (Salix spp.)-cottonwood (Populus spp.) woodland (specifically surrounding Horse Creek), dry saline playas, temporary and intermittent wet meadows, and man-made artesian-fed springs and ditches (Naval Air Station Fallon 2008). The diversity of habitats in NAS Fallon is representative of the plant communities found in the surrounding Great Basin ecoregion.

We conducted a total of 103 active surveys on 47 dates from 4 March to 17 September 


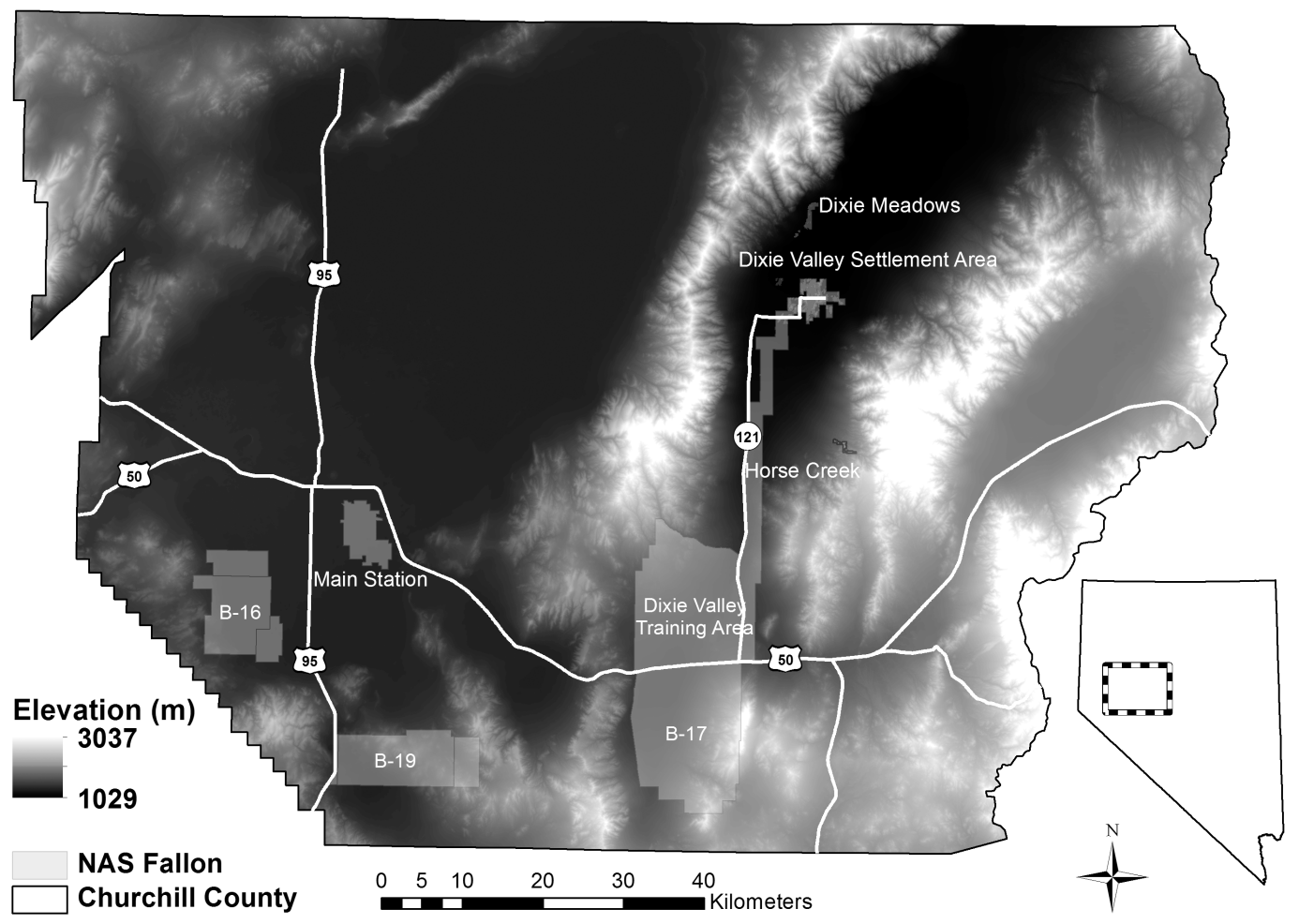

Fig. 1. Map of NAS Fallon parcels surveyed in Churchill County, Nevada, from March to September 2011. The survey areas are overlaid onto a 30-m digital elevation model from the National Elevation Dataset. Inset highlights the location of the study site within Nevada, USA.

2011, with 2 observers per survey, for a total of 337 person-hours of surveying. We focused our survey efforts on detecting amphibians from 4 March to 16 May 2011, and focused detection methods on reptiles from mid-May through the end of our survey in September. We used daytime and nighttime visual encounter surveys (VES), nighttime amphibian calling surveys, and daytime and nighttime road cruising surveys to detect amphibian and reptile species. We identified all observed amphibians and reptiles to species.

The majority of our active surveys (83\%) used VES methods, which we carried out in daylight and after sunset when temperatures were suitable for reptile and amphibian activity. During VES, we walked transects through desert floor habitat, along the edges of streams and springs, and along roads through rocky canyons. We searched for species by turning natural and artificial cover objects and we used dipnets to capture adult and larval amphibians.
Visually surveying for snakes by driving on roads through suitable habitat is a wellestablished, effective method for documenting snake presence (Klauber 1939, Fitch 1949, Campbell 1953). We documented live and dead reptiles on the road during both planned road cruising surveys and opportunistic surveys/ encounters when driving between sites on NAS Fallon.

In addition to our active surveys, we surveyed for calling anurans at wetland habitats by deploying Frogloggers (model SongMeter2 by Wildlife Acoustics), automated recording devices that can be programmed to record audio at regular intervals, for 65 days from 4 March to 8 May 2011. We programmed the Frogloggers to record 3 min of audio every 15 min throughout the survey period. We then listened to recordings and identified calling anurans to species, and followed up with intensive VES at sites where anurans were heard calling.

We documented 18 species on NAS Fallon, including 3 anuran species, 6 snake species, 
and 9 lizard species (Table 1). Dixie Valley Toads (Anaxyrus sp. nov.) were frequently encountered in Dixie Valley Meadows. Although this species has been suggested to be a newly described relict species endemic to this spring-fed system, pending publication of these analyses and a formal description, we group it here with the Western Toad and follow Crother (2012) with respect to the taxonomy of this population. The most commonly encountered amphibians were thus the Western Toad (Anaxyrus boreas boreas) and the nonnative American Bullfrog (Lithobates catesbeianus), of which we observed more than 100 individuals of each species. We also observed adult Great Basin Spadefoot Toads (Spea intermontana) and larvae in extremely shallow ephemeral waters associated with springs or streams (Table 1).

The most commonly encountered lizards were Nevada Side-blotched Lizards (Uta stansburiana nevadensis), followed by Great Basin Fence Lizards (Sceloporus occidentalis longipes) and Great Basin Whiptail Lizards (Aspidoscelis tigris tigris) (Table 1). The lizards with the fewest observations were Great Basin Collared Lizards (Crotaphytus bicinctores) and Northern Desert Horned Lizards (Phrynosoma platyrhinos platyrhinos) (Table 1). The Red Racer (Coluber flagellum piceus) was the most frequently observed snake, followed by the Great Basin Gopher Snake (Pituophis catenifer deserticola) and the Great Basin Rattlesnake (Crotalus oreganus lutosus) (Table 1). Infrequently encountered snakes included the Western Patch-nosed Snake (Salvadora hexalepis), California Kingsnake (Lampropeltis californiae), and Desert Striped Whipsnake (Coluber taeniatus taeniatus) (Table 1).

The 2 most widespread species were Great Basin Whiptail Lizards and Nevada Sideblotched Lizards, which occurred on all 8 parcels of NAS Fallon surveyed (Table 1). Long-nosed Leopard Lizards (Gambelia wizlizenii), Northern Desert Horned Lizards (Phrynosoma platyrhinos platyrhinos), and Zebra-tailed Lizards (Callisaurus draconoides) were also widely distributed and occurred on 7 parcels of NAS Fallon. All 5 of these widespread species occurred in association with desert scrub vegetation communities dominated by sagebrush and Bailey's greasewood, which are widespread on NAS Fallon. Four species were restricted to a single parcel of land (Table 1), 2 of which were snakes observed only once in desert scrub habitat: the California Kingsnake (Lampropeltis californiae) and the Desert Striped Whipsnake (Coluber taeniatus taeniatus). The other 2 species, Western Toad and Northern Sagebrush Lizard (Sceloporus graciosus graciosus) were restricted to suitable spring-fed wet meadow habitats in the Dixie Valley Meadows and mesic mixed woodland habitat with large shade trees (e.g., Fremont cottonwood [Populus fremontii] and saltcedar [Tamarix ramosissima]) in the Dixie Valley Settlement Area, respectively (Table 1).

Eleven of 25 snakes were found during road cruising surveys and the remaining 14 snakes were found during VES. The vast majority of lizards were found during VES, with a few individuals of larger species documented during road cruising surveys. Among lizards, daytime road cruising was especially effective for observing Northern Desert Horned Lizards (4 of 17 total observations).

A species accumulation curve of our survey efforts illustrates that we had observed all 18 species by 14 June 2011 after conducting 62 surveys that totaled $226 \mathrm{~h}$ (Fig. 2). The rapid increase in new species observed during the spring followed by a plateau during early summer (Fig. 2) likely reflects the seasonal activity of amphibians and reptiles in the Great Basin. The cooler, wetter weather during spring and the reproductive activity of many reptiles and amphibians during this time increases the likelihood of observing active animals (Todd et al. 2007), whereas during the hotter summer months many frog and snake species are less active and therefore less likely to be detected.

The seasonal activity of amphibians varied depending on the species. We observed adult American Bullfrogs throughout our surveys from March to September. We only observed adult Great Basin Spadefoot Toads in April, and tadpoles and recently metamorphosed juveniles of this species were seen through June. Adult Western Toads were active in the spring, being seen from March to June. We heard Western Toads calling in March, encountered tadpoles from April to June, and encountered recently metamorphosed individuals in September.

In contrast to most of the snake and frog species, we observed most lizard species throughout the summer, except for Northern 


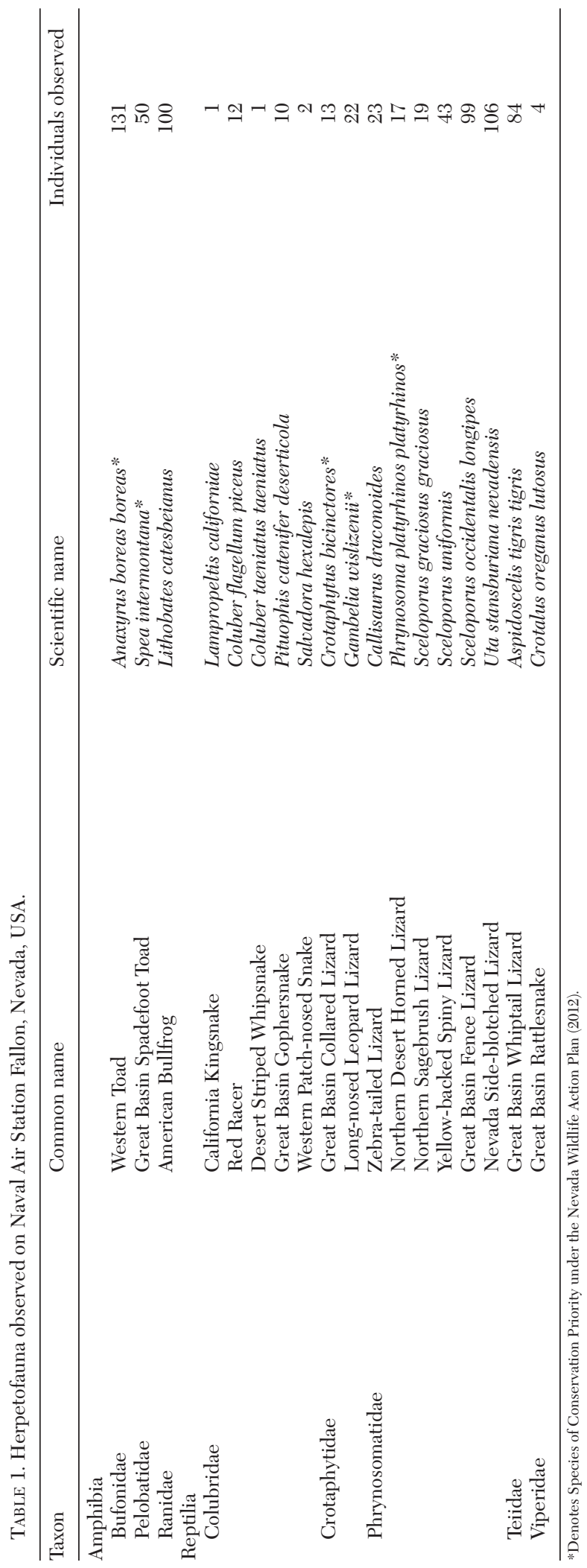



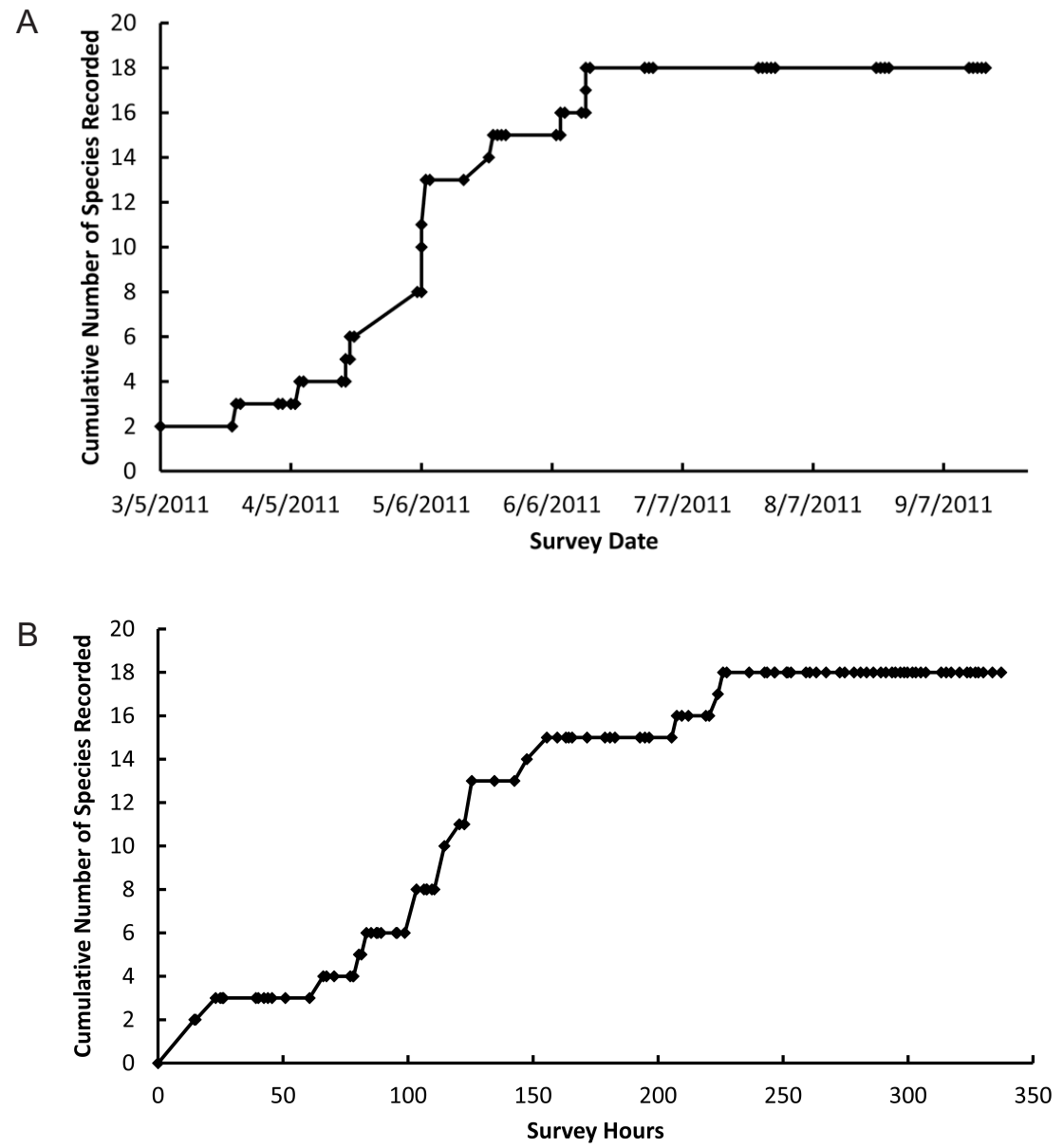

Fig. 2. The cumulative number of amphibian and reptiles species observed on NAS Fallon as a function of survey date (A) or total number of survey hours (B). Eighteen species were observed during the study, and this total was reached on 14 June 2011 after 226 person-hours of surveying.

Desert Horned Lizards (Phrynosoma platyrhinos platyrhinos), which we last observed on 29 July 2011. Beginning in late August, we began to observe neonates of most lizard species, and in August and September we encountered adult lizards less frequently. We encountered only 3 snakes after mid-June, all of which were Red Racers. Though we did not record any new species during the summer months, surveys that continue later into the summer may be valuable if they are directed at addressing a specific question. For example, if the goal of a study is to track the development and metamorphosis of tadpoles, or to estimate the timing of emergence for hatchling lizards, it would be necessary to survey from July to September and possibly later.
The plateau at 18 species seen in our species accumulation curves does not necessarily indicate that we observed every amphibian and reptile species present on NAS Fallon. Our combined VES and road cruising survey effort (337 person-hours) is comparable to some published herpetological inventories in the southwestern United States (e.g., 318 h in Drost et al. 2001; 179 person-hours in Setser et al. 2002) but falls short compared to other extensive, multiyear survey efforts (e.g., 2192 hours over 2 years in Bogosian et al. 2012; 1279 hours over 3 years in Persons and Nowak 2006). Therefore, it is possible that additional effort across years could document other species occurring in this area that went undetected during the present effort. 
Our surveys documented a diverse assemblage of amphibians and reptiles inhabiting NAS Fallon. Despite use by the Navy for training activities including the use of live ordnance, this area maintains suitable habitat for native herpetofauna. None of the species recorded during our surveys is currently listed as threatened or endangered under the federal ESA. However, several species present on NAS Fallon are listed as Species of Conservation Priority (SOCP) under the Nevada Wildlife Action Plan of 2012 (Wildlife Action Plan Team 2012). The Great Basin Spadefoot, Western Toad, Northern Desert Horned Lizard, Long-nosed Leopard Lizard, and Great Basin Collared Lizard are all listed as SOCP due to potential threats such as climate change, energy development, and invasive species (Wildlife Action Plan Team 2012). Therefore, though these species are currently common on NAS Fallon and in some other parts of Nevada, the preservation and restoration of additional habitat may be necessary to ensure they do not become imperiled due to future anthropogenic change.

Perhaps the most notable occurrence on NAS Fallon is a population of Western Toads in the Dixie Meadows that is believed to represent a genetically distinct and novel taxon (C. Richard Tracy personal communication). Individuals in this population reach only half the size at sexual maturity of more typical Western Toads found outside the meadows 15 $\mathrm{km}$ away, and they appear morphologically distinct (Tracy personal communication). The population is also restricted to the Dixie Meadows, which are fed by 2 small springs. Future work using molecular tools to identify the relatedness of this population to Western Toads and other toad species of the American West is still pending (Tracy personal communication). Our documentation of all life stages of these small-bodied toads in the Dixie Meadows wetlands indicated successful recruitment in 2011. If the Western Toad found in the Dixie Meadows is indeed described as a new species, NAS Fallon would represent an important site for the conservation of this seemingly narrowly distributed endemic species.

One SOCP that was notably absent from our surveys was the Northern Leopard Frog. Despite historical records from elsewhere in Churchill County, we did not find any Northern Leopard Frogs on NAS Fallon land during surveys of several wetland habitats that appeared suitable for this amphibian. Northern Leopard Frogs do occur nearby, however, and we found an adult of this species in surveys of Massie Slough, a wetland habitat 16 $\mathrm{km}$ west of the city of Fallon away from NAS Fallon parcels. Given that we did not detect Northern Leopard Frogs in repeated surveys of appropriate habitat on NAS Fallon and that these NAS Fallon wetlands had dense populations of nonnative American Bullfrogs, we believe it is highly unlikely that NAS Fallon supported Northern Leopard Frogs at the time of our surveys.

Six reptile species that could putatively occur on NAS Fallon according to published range maps were undetected during our surveys (Stebbins 2003). The Long-nosed Snake (Rhinocheilus lecontei), the Desert Nightsnake (Hypsiglena chlorophaea), and the Ground Snake (Sonora semiannulata) may all occur on NAS Fallon but were not observed despite extensive VES and road cruising. NAS Fallon also falls within the distribution of the Northern Rubber Boa (Charina bottae), a SOCP in Nevada. Northern Rubber Boas require habitats such as chaparral and pine-oak woodlands (Ernst and Ernst 2003), habitats that are largely absent from NAS Fallon. We think it is thus unlikely that Northern Rubber Boas occur on NAS Fallon. The distribution of the Wandering Gartersnake (Thamnophis elegans vagrans) also overlaps with NAS Fallon parcels but was not detected during our surveys. Given that this species is often common and conspicuous where it occurs, and that we surveyed extensively near all wetland habitats on NAS Fallon, we believe it is unlikely this species occurs on NAS Fallon. The Western Skink (Plestiodon skiltonianus) may also potentially occur on NAS Fallon according to a published range map (Stebbins 2003); however, this species was not seen despite extensive surveys and searching under cover objects.

Our study also corrects 2 findings from an earlier unpublished ecological inventory of NAS Fallon, which stated that Sierran Treefrogs (Pseudacris sierra, formerly Pacific Treefrog, Pseudacris regilla) occur on NAS Fallon, and that Red Racers are absent (Naval Air Station Fallon 2008). We did not see or hear Sierran Treefrogs on NAS Fallon, and we believe the previous report of Sierran Treefrog larvae from this area to be in error. Museum records 
from HerpNet (www.herpnet.org) and the Global Biodiversity Information Facility (www. gbif.org) indicate Sierran Treefrogs have never been documented in Churchill County, and the nearest records were found $64 \mathrm{~km}$ west of Fallon in Storey County, Nevada. We suggest that the previous identification of Sierran Treefrog larvae resulted from misidentified Great Basin Spadefoot Toad larvae, which we found in abundance in the wet meadows of Dixie Valley and along Horse Creek. Similarly, although the earlier ecological inventory reported that Red Racers do not occur in Churchill County, Nevada, or on NAS Fallon lands (Naval Air Station Fallon 2008), we found that this species is in fact relatively widespread, demonstrating the need for continued herpetological inventories and monitoring by trained herpetologists.

Inventory and monitoring of biotic communities are important parts of effective biodiversity conservation and land management. Accurate data on the presence of wildlife on DoD property is vitally important for land managers to balance the demands of conservation while maintaining military readiness and meeting the needs of military training and testing. Our results can guide future decision making such that species that are common and widespread on NAS Fallon today remain so. Several species documented in our surveys are listed as Species of Conservation Priority by the Nevada Wildlife Action Plan, and many lands administered by the DoD support populations of imperiled species (Stein et al. 2008). Therefore, in the face of rapid global change in the 21st century, conservation biologists in the United States must consider DoD properties to be part of the broader portfolio of protected areas instrumental in conserving biodiversity.

This research was funded by the Department of the Navy on behalf of the Installation Naval Air Station Fallon. We thank the Amphibian and Reptile Conservancy for facilitating this project and M.G. Nafus and C.M. Mosser for assisting with fieldwork. This project conformed to the legal requirements for research with vertebrates and was approved by the University of California, Davis, Institutional Animal Care and Use Committee (Protocol 2011-16205). Collection of animals was authorized by Nevada Department of Wildlife Scientific Collection Permit No. S33983.

\section{Literature Cited}

ADAMS, M.J., R.B. Bury, and S.A. SwarTs. 1998. Amphibians of the Fort Lewis Military Reservation, Washington: sampling techniques and community patterns. Northwestern Naturalist 79:12-18.

Bogosian, V., E.C. Hellgren, and R.W. Moody. 2012. Assemblages of amphibians, reptiles, and mammals on an urban military base in Oklahoma. Southwestern Naturalist 57:277-284.

Campbell, H. 1953. Observations on snakes DOR in New Mexico. Herpetologica 9:157-160.

Crother, B.I., editor. 2012. Scientific and standard English names of amphibians and reptiles of North America north of Mexico, with comments regarding confidence in our understanding. 7th edition. SSAR Herpetological Circular 39. 92 pp.

Drost, C.A., T.B. Persons, and E.M. Nowak. 2001. Herpetofauna survey of Petrified Forest National Park, Arizona. Pages 83-102 in C. van Riper III, K.A. Thomas, and M.A. Stuart, editors, Proceedings of the Fifth Biennial Conference of Research on the Colorado Plateau. U.S. Geological Survey/FRESC Report Series USGSFRESC/COPL/2001/24.

EgLin Air Force BASE. 2010. Integrated Natural Resources Management Plan. Department of the Air Force, Eglin Air Force Base, FL.

Ernst, C.H., And E.M. Ernst. 2003. Snakes of the United States and Canada. Smithsonian Books, Washington, DC.

Esque, T.C., K.E. Nussear, and P.A. Medica. 2005. Desert tortoise translocation plan for Fort Irwin's land expansion program at the U.S. Army National Training Center (NTC) \& Fort Irwin. U.S. Army National Training Center, Directorate of Public Works, Fort Irwin, CA.

Fitch, H.S. 1949. Road counts of snakes in western Louisiana. Herpetologica 5:87-90.

Guisan, A., R. Tingley, J.B. Baumgartner, I. NaujokaitisLewis, P.R. Sutcliffe, A.I.T. Tulloch, T.J. Regan, L. Brotons, E. McDonald-Madden, C. MantykaPringle, ET AL. 2013. Predicting species distributions for conservation decisions. Ecology Letters 16: 1424-1435.

KLauber, L.M. 1939. Studies of the reptile life in the arid Southwest. I. Night collecting on the deserts with ecological statistics. Bulletin of the Zoological Society of San Diego 14:1-79.

Lindenmayer, D.B., M.P. Piggott, and B.A. Wintle. 2013. Counting the books while the library burns: why conservation monitoring programs need a plan for action. Frontiers in Ecology and the Environment 11:549-555.

Lovich, R.E., C. Petersen, P. Nanjappa, E. Garcia, and A. Dalsimer. 2014. Draft Department of Defense Partners in Amphibian and Reptile Conservation Strategic Plan. 34 pp.

Naval Air Station FALLON. 2008. Ecological inventory update: Naval Air Station Fallon. Naval Facilities (NAVFAC) Southwest Report Contract N68711-05D-8004/0019, San Diego, CA.

Nichols, J.D., AND B.K. Williams. 2006. Monitoring for conservation. Trends in Ecology and Evolution 21: $668-673$.

Pauly, D. 1995. Anecdotes and the shifting baseline syndrome of fisheries. Trends in Ecology and Evolution 10:430. 
Persons, T.B., AND E.M. NowaK. 2006. Inventory of amphibians and reptiles at Death Valley National Park. U.S. Geological Survey, Southwest Biological Science Center, Colorado Plateau Research Station.

Setser, K., J.M. Meik, and D.G. Mulcahy. 2002. Herpetofauna of the southern Snake Range of Nevada and surrounding valleys. Western North American Naturalist 62:234-239.

Stebbins, R.C. 2003. Western reptiles and amphibians. 3rd edition. Houghton Mifflin, New York, NY.

Stein, B.A., C. Scott, And N. BEnton. 2008. Federal lands and endangered species: the role of military and other federal lands in sustaining biodiversity. BioScience 58:339-347.

Stuart, S.N., J.S. Chanson, N.A. Cox, B.E. Young, A.S.L. RoDrigues, D.L. Fischman, AND R.W. WALLER. 2004. Status and trends of amphibian declines and extinctions worldwide. Science 306:1783-1786.

TodD, B.D., J.D. WiLlson, And J.W. GibBons. 2010. The global status of reptiles and causes of their decline.
Pages 47-67 in D.W. Sparling, G. Linder, C.A. Bishop, and S. Krest, editors, Ecotoxicology of amphibans and reptiles. 2nd edition. CRC Press, Boca Raton, FL.

TodD, B.D., C.T. Winne, J.D. Willson, and J.W. GibBons. 2007. Getting the drift: examining the effects of timing, trap type, and taxon on herpetofaunal drift fence surveys. American Midland Naturalist 158: 292-305.

Wake, D.B., and V.T. Vredenburg. 2008. Are we in the midst of the sixth mass extinction? A view from the world of amphibians. Proceedings of the National Academy of Sciences USA 105:11466-11473.

Wildlife Action Plan Team. 2012. Nevada Wildlife Action Plan. Nevada Department of Wildlife, Reno, NV.

Received 7 April 2015 Accepted 22 September 2015 